\title{
Article
}

\section{Mediators, confounders and effectiveness of interventions for medication adherence after stroke}

Hill, James Edward, Harrison, Joanna, Raj, Sonia, Gregary, Bindu, Timoroksa, Anne-Marie and Gibson, Josephine

Available at http://clok.uclan.ac.uk/35451/

Hill, James Edward ORCID: 0000-0003-1430-6927, Harrison, Joanna ORCID: 0000-0001-8963-7240, Raj, Sonia, Gregary, Bindu, Timoroksa, Anne-Marie and Gibson, Josephine ORCID: 0000-0002-3051-1237 (2020) Mediators,

confounders and effectiveness of interventions for medication adherence after stroke. British Journal of Neuroscience Nursing, 16 (Sup5). S18-S24. ISSN $1747-0307$

It is advisable to refer to the publisher's version if you intend to cite from the work. 10.12968/bjnn.2020.16.sup5.s18

For more information about UCLan's research in this area go to

http://www.uclan.ac.uk/researchgroups/ and search for < name of research Group>.

For information about Research generally at UCLan please go to http://www.uclan.ac.uk/research/

All outputs in CLoK are protected by Intellectual Property Rights law, including Copyright law. Copyright, IPR and Moral Rights for the works on this site are retained by the individual authors and/or other copyright owners. Terms and conditions for use of this material are defined in the policies page.

\section{CLoK}

Central Lancashire online Knowledge www.clok.uclan.ac.uk

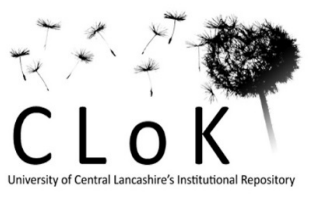




\title{
Mediators, confounders and effectiveness of interventions for medication adherence after stroke.
}

\author{
Commentary on:
}

- Al AlShaikh S, Quinn T, Dunn W, Walters M, Dawson J. Predictive factors of non-adherence to secondary preventative medication after stroke or transient ischaemic attack: A systematic review and metaanalyses. Eur Stroke J. 2016;1(2):65-75.

- Bridgwood B, Lager KE, Mistri AK, Khunti K, Wilson AD, Modi P. Interventions for improving modifiable risk factor control in the secondary prevention of stroke. The Cochrane database of systematic reviews. 2018;5:Cd009103.

- Gibson JME, Miller C, Coupe J, Jones SP. Medication-taking after stroke: a qualitative meta-synthesis of the perspectives of stroke survivors, informal carers and health professionals. Fam Pract. 2020;37(1):4-

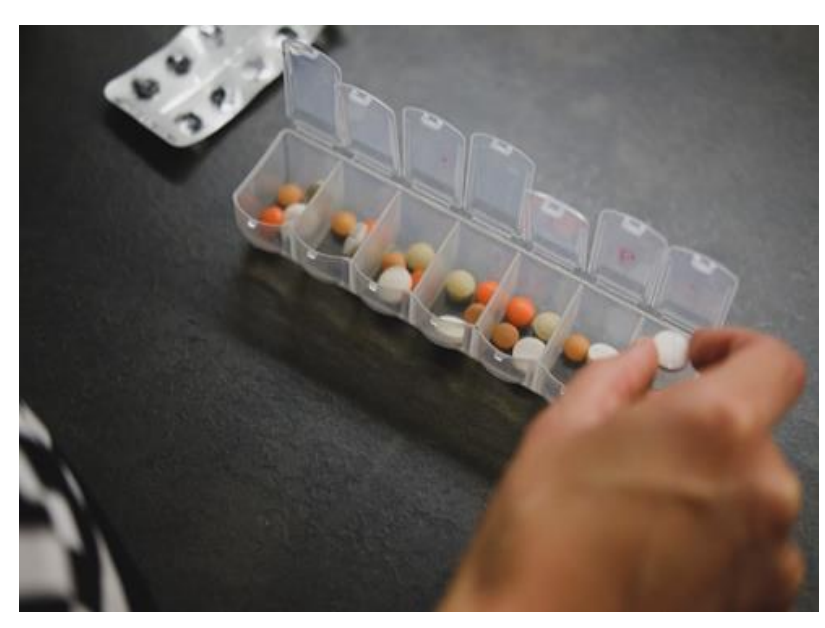

KEY POINTS

- Patients who present with an existing disability, reduced cognitive function, take multiple medications, have a poor quality of life, and have had a previous stroke are associated with reduced medication adherence.

- There is evidence that trust and belief in the medication are important modifiable factors which are linked to positive medication adherence.

- There is some evidence that education may be effective for improving medication adherence.

\section{Background to the reviews}

There are 13.7 million new stroke cases globally per year, with a total of 80.1 million stroke survivors (GBD 2019). It is the second most common cause of death in the world and is attributed to 6.17 million deaths per year (GBD 2018). Around one in four people can expect to have a stroke within their lifetime (Feigin et al. 2017). The consequences of stroke can include reduced mobility (Michael et al. 2005), limb weakness, spasticity, pain, psychosocial issues, language difficulties (Norrving and Kissela 2013) and reduced quality of life (Bays 2001).

After a stroke or a transient ischaemic attack [TIA] people have a substantial long-term risk of recurrent stroke (van Wijk et al. 2005; Dhamoon et al. 2006; Feng et al. 2010; Edwards et al. 2017). Secondary prevention medication is an important (Kikuchi et al. 2012; Hankey 2014) and effective strategy to reduce the risk of stroke recurrence (Toyoda 2009; Hill and Hare 2019). However, medication adherence and medication persistence rates are low after stroke (Zhang et al. 2019). It is 
important to understand stroke survivors' and carers' experiences of medication-taking after stroke, barriers and facilitators of medication adherence, and the effectiveness of interventions to improve them in order to provide effective support.

This commentary aims to critically appraise the methods used within three systematic reviews exploring medication adherence after stroke (AlShaikh et al 2016, Bridgwood et al 2018, Gibson et al 2020) and to synthesise the findings in the context of clinical practice.

\section{Methods and Quality of the reviews}

Selection of reviews was based on relevance to the broader issues surrounding medication adherence in a stoke population, rather than focussing on one moderating factor, e.g. the association with cognitive impairment. Additionally, they were the most recent reviews in this area.

The three reviews focused on specific populations of stroke survivors (Al AlShaikh et al. 2016; Bridgwood et al. 2018; Gibson et al. 2020) and informal primary and secondary care (Gibson et al. 2020). They used qualitative and quantitative review techniques to explore three key aspects of medication adherence:

1. Quantitative - Meta-analysis: What are the important moderating factors in relation to medication non-adherence after stroke? (Al AlShaikh et al. 2016).

2. Qualitative - Meta-ethnography: What are the views and lived experiences of communitydwelling stroke survivors, caregivers and health care professionals related to medication taking? (Gibson et al. 2020).

3. Quantitative - Meta-analysis: What interventions are effective in improving medication taking? (Bridgwood et al. 2018).

Outcomes for the reviews explored views, experiences, beliefs, strategies, solutions, factors which influence adherence, and adherence itself. Using the PICO tool (Schardt et al. 2007) as an organising framework, components of clinical evidence were compared for each review (see Table 1).

Table 1: PICO of AlShaikh et al 2016, Gibson et al 2019 and Bridgwood et al 2018

\begin{tabular}{|l|l|l|l|}
\hline PICO & (AlShaikh et al 2016) & (Gibson et al 2019) & (Bridgwood et al 2018) \\
\hline Population & $\begin{array}{l}\text { Adults who have } \\
\text { suffered a stroke }\end{array}$ & $\begin{array}{l}\text { Community-dwelling } \\
\text { stroke or TIA survivors, } \\
\text { informal carers, primary or } \\
\text { secondary care HCPs who } \\
\text { prescribe medication- } \\
\text { taking after TIA or stroke }\end{array}$ & $\begin{array}{l}\text { Adults with a confirmed } \\
\text { diagnosis of ischaemic stroke, } \\
\text { haemorrhagic stroke, or TIA }\end{array}$ \\
\hline $\begin{array}{l}\text { Exposure/ } \\
\text { Intervention }\end{array}$ & $\begin{array}{l}\text { Prescribed medication } \\
\text { for the } \\
\text { prevention of recurrent } \\
\text { cardiovascular events }\end{array}$ & $\begin{array}{l}\text { Being prescribed or being } \\
\text { involved in the } \\
\text { prescription of medication }\end{array}$ & $\begin{array}{l}\text { Interventions which aimed to } \\
\text { improve modifiable risk factor } \\
\text { control through increased } \\
\text { adherence }\end{array}$ \\
\hline Control & $\begin{array}{l}\text { Factor(s) that influenced } \\
\text { medication adherence. }\end{array}$ & $\begin{array}{l}\text { Lived experiences, views } \\
\text { and } \\
\text { beliefs, strategies and applical care } \\
\text { solutions. }\end{array}$ & $\begin{array}{l}\text { Patient outcomes such as } \\
\text { body mass index, blood } \\
\text { pressure, and any indicator of } \\
\text { patient adherence }\end{array}$ \\
\hline Outcomes & &
\end{tabular}




\begin{tabular}{|l|l|l|l|}
\hline Study type & No study type specified. & $\begin{array}{l}\text { Qualitative studies and } \\
\text { mixed methods }\end{array}$ & $\begin{array}{l}\text { Randomised controlled trials, } \\
\text { parallel group trials, cluster- } \\
\text { randomised } \\
\text { trials and cross-over trials }\end{array}$ \\
\hline
\end{tabular}

Using a modified Joanna Briggs Institute Critical Appraisal tool for systematic reviews (Joanna Briggs Institute 2017), it was judged that the systematic reviews by Gibson et al 2020 and Bridgwood et al 2018 used appropriate methods for all 11 criteria (See Table 2 for full list of criteria and corresponding methods) and provided an accurate summary of the results of the included studies. The other systematic review (AlShaikh et al 2016) used appropriate methods for only 9 of 11 criteria. The screening methods were not appropriate, as although the first stage of dual independent title screening was appropriate (Mateen 2013; Rathbone et al. 2017), the second stage of single reviewer full paper screening was not (Buscemi et al. 2006; Waffenschmidt et al. 2019). The review also lacked a description of the data extraction methods used. Both of these issues can lead to errors and exclusion of eligible studies, but overall AlShaikh et al (2016) probably provides an accurate summary of the results of the available studies.

Table 2: Quality assessment and methods of AlShaikh et al 2016, Gibson et al 2019 and Bridgwood et al 2018 (Quality assessment of the systematic reviews was carried out by JH and JH).

\begin{tabular}{|c|c|c|c|}
\hline Criteria & (AlShaikh et al 2016) & (Gibson et al 2019) & (Bridgwood et al 2018) \\
\hline $\begin{array}{l}\text { 1. Is the review } \\
\text { question clearly } \\
\text { and explicitly } \\
\text { stated? }\end{array}$ & $\begin{array}{l}\text { Yes: The aim of this } \\
\text { review was to identify } \\
\text { factors associated with } \\
\text { non-adherence after } \\
\text { stroke. }\end{array}$ & $\begin{array}{l}\text { Yes: The aim of this } \\
\text { review was to } \\
\text { undertake a meta- } \\
\text { synthesis of qualitative } \\
\text { studies of medication- } \\
\text { taking after stroke. } \\
\text { With a focus on lived } \\
\text { experiences, views and } \\
\text { beliefs, strategies and } \\
\text { solutions. }\end{array}$ & $\begin{array}{l}\text { Yes: To assess the } \\
\text { effects of stroke service } \\
\text { interventions for } \\
\text { implementing } \\
\text { secondary stroke } \\
\text { prevention strategies } \\
\text { on modifiable risk } \\
\text { factor control. }\end{array}$ \\
\hline $\begin{array}{l}2 . \text { Were the } \\
\text { inclusion criteria } \\
\text { appropriate for } \\
\text { the review } \\
\text { question? }\end{array}$ & $\begin{array}{l}\text { Yes: See Table } 1 \text { for full } \\
\text { PICO criteria. }\end{array}$ & $\begin{array}{l}\text { Yes: See Table } 1 \text { for full } \\
\text { PICO criteria. }\end{array}$ & $\begin{array}{l}\text { Yes: See Table } 1 \text { for full } \\
\text { PICO criteria. }\end{array}$ \\
\hline $\begin{array}{l}\text { 3. Was the search } \\
\text { strategy } \\
\text { appropriate? }\end{array}$ & $\begin{array}{l}\text { Yes: A robust multi- } \\
\text { database search was } \\
\text { undertaken. }\end{array}$ & 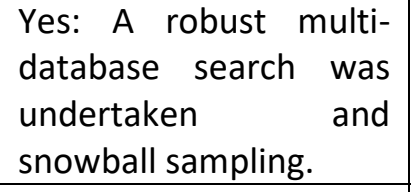 & $\begin{array}{l}\text { Yes: A robust multi- } \\
\text { database search was } \\
\text { undertaken } \\
\text { snowball sampling. }\end{array}$ \\
\hline $\begin{array}{l}\text { 4. Were the } \\
\text { sources and } \\
\text { resources used to } \\
\text { screen studies } \\
\text { adequate? }\end{array}$ & $\begin{array}{l}\text { No: The first stage of } \\
\text { screening used two } \\
\text { reviewers } \\
\text { independently } \\
\text { reviewing titles only. } \\
\text { Full paper screening } \\
\text { was done by single } \\
\text { reviewer. }\end{array}$ & $\begin{array}{l}\text { Yes: Title and full paper } \\
\text { screening was carried } \\
\text { out by two } \\
\text { independent reviewers }\end{array}$ & $\begin{array}{l}\text { Yes: Title and full paper } \\
\text { screening was carried } \\
\text { out by two } \\
\text { independent reviewers }\end{array}$ \\
\hline 5.Were & Yes: Pre-specified tool & Yes: The use of Walsh & Yes: All included studies \\
\hline
\end{tabular}




\begin{tabular}{|c|c|c|c|}
\hline $\begin{array}{l}\text { criteria for } \\
\text { appraising studies } \\
\text { appropriate? }\end{array}$ & $\begin{array}{l}\text { based upon Newcastle- } \\
\text { Ottawa } \\
\text { Scales (Wells 2019) and } \\
\text { Cochrane Library tool } \\
\text { for assessing risk of bias } \\
\text { was used (Higgins et al. } \\
2011 \text { ). }\end{array}$ & $\begin{array}{l}\text { and Downe's criteria } \\
\text { was used to assess the } \\
\text { quality of the included } \\
\text { studies. }\end{array}$ & $\begin{array}{l}\text { were assessed using } \\
\text { the Cochrane risk of } \\
\text { bias tool (Higgins et al. } \\
\text { 2011) }\end{array}$ \\
\hline $\begin{array}{l}\text { 6. Was critical } \\
\text { appraisal } \\
\text { conducted by two } \\
\text { or more } \\
\text { reviewers } \\
\text { independently? }\end{array}$ & $\begin{array}{lr}\text { Yes: Two } & \text { independent } \\
\text { reviewers } & \text { critically } \\
\text { appraised all included } \\
\text { studies }\end{array}$ & $\begin{array}{l}\text { Yes: Two independent } \\
\text { reviewers } \\
\text { appraised all included } \\
\text { studies }\end{array}$ & $\begin{array}{l}\text { Yes: Three independent } \\
\text { reviewers critically } \\
\text { appraised all included } \\
\text { studies }\end{array}$ \\
\hline $\begin{array}{lr}\text { 7. Were } & \text { there } \\
\text { methods } & \text { to } \\
\text { minimize errors } \\
\text { in } & \text { data } \\
\text { extraction? } & \end{array}$ & $\begin{array}{l}\text { No: No description of } \\
\text { whether data extraction } \\
\text { was carried out } \\
\text { independently and } \\
\text { duplicated. }\end{array}$ & $\begin{array}{l}\text { Yes: Data extraction } \\
\text { was carried out by two } \\
\text { independent reviewers } \\
\text { using a bespoke pre- } \\
\text { piloted data extraction } \\
\text { form. }\end{array}$ & $\begin{array}{l}\text { Yes: Data extraction } \\
\text { was carried out by two } \\
\text { independent reviewers } \\
\text { using a pre-specified } \\
\text { data extraction form }\end{array}$ \\
\hline $\begin{array}{l}\text { 8. Were the } \\
\text { methods used to } \\
\text { combine studies } \\
\text { appropriate? }\end{array}$ & $\begin{array}{l}\text { Yes: A random effects } \\
\text { model was used. }\end{array}$ & $\begin{array}{l}\text { Yes: The use of the } \\
\text { meta-synthesis } \\
\text { technique by Noblit } \\
\text { and Hare was used } \\
\text { (Noblit 1988). }\end{array}$ & $\begin{array}{l}\text { Yes: A random effects } \\
\text { model was used for } \\
\text { each prespecified } \\
\text { intervention category; } \\
\text { subgroup analysis was } \\
\text { carried out for patient } \\
\text { age, condition type, } \\
\text { stroke severity and } \\
\text { specific risk factor } \\
\text { management strategy }\end{array}$ \\
\hline $\begin{array}{lr}\text { 9. Was } & \text { the } \\
\text { likelihood } & \text { of } \\
\text { publication bias } \\
\text { assessed? }\end{array}$ & $\begin{array}{l}\text { N/A: Less than } 10 \\
\text { studies (Higgins et al. } \\
\text { 2011). }\end{array}$ & $\mathrm{N} / \mathrm{A}$ & $\begin{array}{l}\text { Yes: Only visual } \\
\text { inspection of funnel } \\
\text { plots. }\end{array}$ \\
\hline $\begin{array}{l}\text { 10.Were } \\
\text { recommendation } \\
\text { s for policy } \\
\text { and/or practice } \\
\text { supported by the } \\
\text { reported data? }\end{array}$ & $\begin{array}{l}\text { Yes: Full findings and } \\
\text { implications to practice } \\
\text { will be discussed below. }\end{array}$ & $\begin{array}{l}\text { Yes: Full findings and } \\
\text { implications to practice } \\
\text { will be discussed } \\
\text { below. }\end{array}$ & $\begin{array}{l}\text { Yes: Full findings and } \\
\text { implications to practice } \\
\text { will be discussed } \\
\text { below. }\end{array}$ \\
\hline $\begin{array}{l}\text { 11. Were the } \\
\text { specific directives } \\
\text { for new research } \\
\text { appropriate? }\end{array}$ & $\begin{array}{l}\text { Yes: Recommendation } \\
\text { that further research is } \\
\text { required around which } \\
\text { interventions are } \\
\text { effective in improving } \\
\text { treatment adherence. }\end{array}$ & $\begin{array}{l}\text { Yes: Particular areas of } \\
\text { lack of research were } \\
\text { identified in studies in } \\
\text { low to moderate } \\
\text { income countries, } \\
\text { acute post stroke and } \\
\text { carers and healthcare } \\
\text { professional's } \\
\text { perception } \\
\text { medication adherence. }\end{array}$ & $\begin{array}{l}\text { Yes: Appropriate } \\
\text { recommendations were } \\
\text { made based on the } \\
\text { findings of the study }\end{array}$ \\
\hline $\begin{array}{l}\text { Total criteria } \\
\text { achieved/not }\end{array}$ & $8 / 11$ & $11 / 11$ & $11 / 11$ \\
\hline
\end{tabular}




\section{Quality of studies included in the reviews}

The systematic review by AlShaikh et al (2016) identified that the majority of studies had a high risk of bias: often, outcome assessors were non-blinded and most studies used only self-reporting of adherence. The qualitative systematic review by Gibson et al (2019) identified that the majority of studies included were of medium quality. Quality issues included lack of an appropriate theoretical framework, data saturation, participant validation, and reporting of important patient data. There were also some ethical concerns. The review by Bridgwood et al (2018) classified the evidence for the outcome of adherence to be of low-quality using GRADE (Kavanagh, 2009), because the studies included were heterogeneous, had high risk of bias and findings were inconsistent across the studies. The authors concluded that the true effect might be markedly different from the estimated effect (Bridgwood et al 2018) See Table 3 for summarisation of quality of included studies.

Table 3: Quality of studies included in the reviews.

\begin{tabular}{|c|c|c|c|}
\hline & AlShaikh et al (2016) & Gibson et al (2020) & Bridgwood et al (2018) \\
\hline $\begin{array}{l}\text { Critical appraisal } \\
\text { tool used for } \\
\text { summary statement } \\
\text { of quality }\end{array}$ & $\begin{array}{l}\text { Scales (Wells 2019) } \\
\text { and Cochrane Library } \\
\text { tool (Higgins et al. } \\
\text { 2011) }\end{array}$ & $\begin{array}{l}\text { Walsh and Downe's } \\
\text { criteria (Walsh and } \\
\text { Downe 2006) }\end{array}$ & $\begin{array}{l}\text { GRADE (Kavanagh, } \\
\text { 2009) }\end{array}$ \\
\hline Quality score & $\begin{array}{l}\text { Out of the } 29 \\
\text { included studies } 27 \\
\text { were deemed to be } \\
\text { of high risk and } 2 \\
\text { were low. }\end{array}$ & $\begin{array}{l}\text { Of the } 12 \text { included } \\
\text { studies } 9 \text { were } \\
\text { deemed to be of } \\
\text { moderate quality and } \\
3 \text { were deemed to be } \\
\text { of weak quality }\end{array}$ & $\begin{array}{l}\text { The outcome of } \\
\text { medication adherence } \\
\text { was downgraded due to } \\
\text { heterogeneity, high risk } \\
\text { of bias and } \\
\text { inconsistency }\end{array}$ \\
\hline Descriptive term: & $\begin{array}{l}\text { High risk of bias } \\
\text { (study } \\
\text { level } \\
\begin{array}{l}\text { assessment of risk of } \\
\text { bias) }\end{array}\end{array}$ & $\begin{array}{lr}\text { “Medium } & \text { quality" } \\
\text { (study } & \text { level } \\
\text { assessment } & \text { of } \\
\text { quality) } & \end{array}$ & Low quality evidence \\
\hline
\end{tabular}

Findings

Important factors - Medication non-adherence

AlShaikh (2016) identified predictive factors of non-adherence to secondary preventive medication after stroke/TIA. The review included 16 studies and 69,137 patients. All included studies provided a measure of medication non-adherence, ranging from $11.3 \%$ to $45.2 \%$. Meta-analysis showed that overall, nearly a third (30.9\%) of participants did not adhere to preventative medication.

The authors reported their data according to the World Health Organization (WHO) classification of predictive factors of non-adherence: patient-related, social and economic, therapy-related, health 
system or health care team, and condition (stroke)-related factors (World Health Organisation 2003). The most commonly reported factors which related to increased medication adherence were patients who have a positive belief in the medication, the presence of a carer or living in a care home, understanding of the medication rationale and having previous treatment by the same medication class respectively. The most commonly reported factors which related to reduced medication adherence were patients who have a disability

reduced cognitive function, number and frequency of prescribed drugs, more severe stroke and concerns about their medication. See Table 4 most frequently reported medication adherence factors.

Table 4: Medication adherence associated factors

\begin{tabular}{|c|c|c|c|}
\hline $\begin{array}{l}\text { World Health } \\
\text { Organization (WHO) } \\
\text { classification }\end{array}$ & Patient related factors & $\begin{array}{l}\text { Number of studies } \\
\text { which reported the } \\
\text { factor to be significant }\end{array}$ & $\begin{array}{c}\text { Positively or } \\
\text { negatively } \\
\text { associated }\end{array}$ \\
\hline \multirow[t]{2}{*}{$\begin{array}{l}\text { Patient related } \\
\text { factors }\end{array}$} & $\begin{array}{l}\text { Patients who reported } \\
\text { with concerns about } \\
\text { their medication }\end{array}$ & 4 & Negatively \\
\hline & $\begin{array}{l}\text { Patients had a positive } \\
\text { belief in the medication }\end{array}$ & 4 & Positively \\
\hline \multirow[t]{2}{*}{$\begin{array}{l}\text { Socioeconomic } \\
\text { factors }\end{array}$} & $\begin{array}{l}\text { Presence of a carer or } \\
\text { living at home rather } \\
\text { than in institutional } \\
\text { care }\end{array}$ & 4 & Positively \\
\hline & $\begin{array}{l}\text { Having some sort of } \\
\text { education }\end{array}$ & 2 & Positively \\
\hline \multirow{6}{*}{$\begin{array}{l}\text { Therapy-related } \\
\text { factors }\end{array}$} & Disability & 6 & Negatively \\
\hline & $\begin{array}{l}\text { Reduced cognitive } \\
\text { function }\end{array}$ & 4 & Negatively \\
\hline & Poor quality of life & 3 & Negatively \\
\hline & Low mood & 2 & Negatively \\
\hline & Smoking & 2 & Negatively \\
\hline & Alcohol consumption & 2 & Negatively \\
\hline \multirow[t]{4}{*}{$\begin{array}{l}\text { Prescribed regimen } \\
\text { factors }\end{array}$} & $\begin{array}{l}\text { Understanding of } \\
\text { medication } \\
\text { rationale }\end{array}$ & 4 & Positively \\
\hline & $\begin{array}{l}\text { Previous } \\
\text { treatment by the same } \\
\text { medication class }\end{array}$ & 3 & Positively \\
\hline & Cost of medication & 3 & Negatively \\
\hline & $\begin{array}{l}\text { Number and frequency of } \\
\text { prescribed drugs }\end{array}$ & 4 & Negatively \\
\hline \multirow{3}{*}{$\begin{array}{l}\text { Health system or } \\
\text { health care team } \\
\text { factors }\end{array}$} & Treated in stroke unit & 2 & Positively \\
\hline & Medical insurance & 2 & Positively \\
\hline & $\begin{array}{l}\text { Accessible health care } \\
\text { facility }\end{array}$ & 2 & Positively \\
\hline \multirow[t]{3}{*}{ Stroke-related factors } & More severe stroke & 4 & Negatively \\
\hline & Previous stroke incidence & 3 & Negatively \\
\hline & $\begin{array}{l}\text { Symptoms of post- } \\
\text { traumatic stress disorder }\end{array}$ & 2 & Negatively \\
\hline
\end{tabular}


Four factors were eligible for meta-analysis: absent history of atrial fibrillation, disability, polypharmacy and age of the patient, but no significant associations with medication adherence were found.

The review authors noted that much of the available literature was based on patient or drug factors, but institution or healthcare factors should not be forgotten. They suggest that clinicians could reduce the burden of treatment on patients by communicating the barriers of adherence and identifying factors that could be reversed such as mis-beliefs or complex regimens. The authors imply that it is important to identify interventions that can detect difficulties for medication administration and effectively support patients to adhere to secondary preventative medication.

\section{Views and lived experiences related to medication taking}

Gibson et al. (2020) explore the views and lived experiences of taking medicine after stroke from the perspective of community-dwelling stroke survivors, informal carers, and healthcare professionals. The review identified 12 studies including 412 participants, of which two thirds were stroke survivors between 1 month to 20 years post-stroke.

Two overall themes were developed: 'doing medicines work' (all the work that goes into taking medications) and 'trust' (having trust in the medicines' efficacy and beliefs about healthcare). The theme of 'doing medicines work' included several types of work: information work, healthcare work, carer work, emotional work, and practical work, which were classified as sub-themes.

'Information work' focussed on the work patients do to understand and process the information about their medication such as why they are taking it and how to take it. Healthcare professionals are often the ones to provide this information and stroke survivors reported both positive and negative interactions in this respect. With healthcare professionals taking the time to explain the medications and answering questions to be a positive example of information work. However, it was felt that this positive experience was inconsistently delivered and there was a need for medication information to be provided long-term.

The sub-theme of 'healthcare work' provided further insight into how patients engage with healthcare services to obtain their medication, including monitoring and medicines reviews. Positive aspects included healthcare professionals being responsive to patients' medication concerns and difficulties. Negative aspects included patients' dislike of monitoring/review and the perceived negative consequence of additional medication being prescribed.

'Carer work' included support given by family members, friends, or neighbours to obtain, organize or supervise medication for the stroke survivor. It was acknowledged that this could cause conflict in the relationship and give rise to difficulties if the carer were not available.

'Emotional work' described the thoughts and feelings of stroke survivors as to why they need to take medication, primarily to avoid having another stroke. This was seen by healthcare professionals as a key motivator for medication adherence. Within this theme it was also noted that some stroke survivors had concerns about or disliked taking medication due to, for example, potential sideeffects and stigma. 
'Practical work' included the necessary activity required for a stroke survivor to take their medication such as storing and keeping track of doses, often relying on interaction with carers. Successful medication adherence required maintenance of a stable routine. In contrast a complex routine or one that required modification acted as a barrier to medication adherence.

The second main theme in this review was 'trust'. This relates to stroke survivors' and carers' belief in the efficacy of the prescribed medication. This could be hampered by the lack of obvious immediate benefit, but if there was a visible end point such as blood pressure reduction, this enhanced their trust in the efficacy of the medication. Furthermore, taking medication was mediated by a mutual trust between patients, carers and healthcare professionals.

The authors conclude that the substantial work required in 'medicines work' and the need for 'trust' in both the medicines and healthcare service 'are likely to constitute a substantial treatment burden regardless of the severity of the stroke'. In order to address this burden, the authors propose that healthcare professionals need to offer a clear information exchange with stroke survivors, reducing the amount of work involved for patients in accessing medication support, develop individualised strategies to address practical problems, help carers to support and ensure that patient concerns about medication and recurrent stroke are addressed.

\section{What is effective in improving medication taking after stroke?}

The Cochrane review by Bridgwood et al. (2018) synthesised studies of interventions for improving modifiable risk factor control in secondary prevention of stroke. The authors identified 42 random controlled trials [RCTs] with 33,840 participants, mostly in primary care or community settings. Twenty-six studies evaluated organisational interventions (changing how the healthcare service is provided) and 16 evaluated educational or behavioural interventions for participants. Most interventions lasted between three and twelve months with follow up from three months to three years. For most of the interventions, the comparator was standard care (30 RCTs). The remaining studies used active control comparators (4 RCTs) or provided educational but not individualised advice (7 RCTs). One study asked the control group to record stroke consultations/adverse events.

Organisational interventions consisted of those that formed part of a broader rehabilitation programme post-stroke (7 RCTs) and those that targeted secondary prevention (19 RCTs). Eight of these RCTs included a measure of adherence to secondary preventative medications. There was moderate quality evidence that organisational interventions resulted in improved outcomes for blood pressure target achievement compared to usual care $(89$ more per 1000 achieving their target, 95\% Cl: 21 more to 159 more). The eight RCTs which included a measure of adherence were not pooled due to substantial heterogeneity in the methods used. The majority of RCTs [low quality evidence] did not find a statistically significant difference for organisational interventions compared to control. The two RCTs which found a statistically significant difference in medication adherence included lifestyle counselling and blood pressure monitoring (Hornnes 2010; McAlister 2014).

Educational/behavioural interventions largely focussed on modifiable risk factors for stroke (11 RCTs). The remaining interventions delivered education on secondary stroke prevention as part of broader stroke education programmes (5 RCTs). Thirteen of these studies included a measure of adherence to secondary preventative medications. Data could not be pooled due to methodological heterogeneity. The majority of RCTs [low quality evidence] did not find a statistically significant difference for educational/behavioural interventions compared to control. All three studies which demonstrated a statistically significant difference compared to control included education 
specifically focused on medication adherence (O'Carroll 2011; Peng 2014; Wan 2016). Two of the RCTs included specific goal setting around improving medication adherence routines (O'Carroll 2011; Wan 2016).

Within the wider review, the authors found no clear evidence that organisational interventions can improve modifiable risk factors or reduce incidence of cardiovascular events. In addition, educational interventions alone are unlikely to bring improvements without additional organisational change. They also noted that interventions which were associated with improved outcomes for secondary prevention, usually involved multidisciplinary team working. Medication adherence could therefore be improved through reinforcement of information by different team members. 


\section{Application to practice}

Patients who present with an existing disability, reduced cognitive function, take multiple medications, have a poor quality of life, and have had a previous stroke are associated with reduced medication adherence. Subsequently these groups should be seen as a priority for screening and treatment.

There is evidence that trust and belief in the medication are important modifiable factors which are linked to positive medication adherence. Thus, it is important to ensure that the patient has trust and belief in the effectiveness of the medications being prescribed. This concept of trust has also been identified as an important moderating factor for the mutual trust between patient, carers, and healthcare workers and should be seen as a vital component of effective medication adherence interventions.

It is important that patients are provided with information about why the medication is given. This medication information should be clear, easy to access, continuous, responsive, individualised, and accessible for both patients and healthcare workers. The information given to the patient about their medication should be given in a timely manner and opportunities should be given to the patient to voice any concerns/questions they may have. When designing the medication strategy, the regularity of the routine should be considered, as lack of consistency may cause worsened medication adherence. As part of this educational strategy the use of goal setting and outcome monitoring such as blood pressure should be considered.

\section{Keywords}

Stroke, medication taking, medication adherence, predictive factors, education

\section{CPD reflective questions}

- Which out of the factors identified, which were associated with medication adherence, are modifiable?

- If you are designing an educational strategy for medication adherence what key factors should be included?

- Can any of the strategies identified within this paper be applied to your own area of practice?

This report is independent research funded by the National Institute for Health Research Applied Research Collaboration North West Coast (ARC NWC). The views expressed in this publication are those of the author(s) and not necessarily those of the National Institute for Health Research, the NHS, or the Department of Health and Social Care 


\section{References}

Al AlShaikh S, Quinn T, Dunn W, Walters M, Dawson J. 2016. Predictive factors of non-adherence to secondary preventative medication after stroke or transient ischaemic attack: A systematic review and meta-analyses. Eur Stroke J. 1(2):65-75.

Bays CL. 2001. Quality of life of stroke survivors: a research synthesis. J Neurosci Nurs. 33(6):310316.

Bridgwood B, Lager KE, Mistri AK, Khunti K, Wilson AD, Modi P. 2018. Interventions for improving modifiable risk factor control in the secondary prevention of stroke. The Cochrane database of systematic reviews. 5:Cd009103. eng.

Buscemi N, Hartling L, Vandermeer B, Tjosvold L, Klassen TP. 2006. Single data extraction generated more errors than double data extraction in systematic reviews. Journal of clinical epidemiology. 59(7):697-703. eng.

Dhamoon MS, Sciacca RR, Rundek T, Sacco RL, Elkind MS. 2006. Recurrent stroke and cardiac risks after first ischemic stroke: the Northern Manhattan Study. Neurology. 66(5):641-646.

Edwards JD, Kapral MK, Fang J, Swartz RH. 2017. Long-term morbidity and mortality in patients without early complications after stroke or transient ischemic attack. CMAJ. 189(29):E954-E961. eng.

Feigin VL, Norrving B, Mensah GA. 2017. Global Burden of Stroke. Circulation Research. 120(439448). eng.

Feng W, Hendry RM, Adams RJ. 2010. Risk of recurrent stroke, myocardial infarction, or death in hospitalized stroke patients. Neurology. 74(7):588-593.

GBD. 2018. Global, regional, and national age-sex-specific mortality for 282 causes of death in 195 countries and territories, 1980-2017: a systematic analysis for the Global Burden of Disease Study 2017. GLOBAL HEALTH METRICS. 392(10159):1736 - 1788.

GBD. 2019. Global, regional, and national burden of stroke, 1990-2016: a systematic analysis for the Global Burden of Disease Study 2016. GBD 2016 Stroke Collaborators 18(5):439 - 458

Gibson JME, Miller C, Coupe J, Jones SP. 2020. Medication-taking after stroke: a qualitative metasynthesis of the perspectives of stroke survivors, informal carers and health professionals. Fam Pract. 37(1):4-14.

Hackam DG, Spence JD. 2007. Combining multiple approaches for the secondary prevention of vascular events after stroke: a quantitative modeling study. Stroke. 38(6):1881-1885.

Hankey GJ. 2014. Secondary stroke prevention. The Lancet Neurology. 13(2):178-194. eng.

Higgins JPT, Altman DG, Gøtzsche PC, Jüni P, Moher D, Oxman AD, Savović J, Schulz KF, Weeks L, Sterne JAC. 2011. The Cochrane Collaboration's tool for assessing risk of bias in randomised trials. BMJ. 343:d5928.

Hill J, Hare M. 2019. Statins used for secondary prevention in patients with stroke reduce the risk of further ischaemic strokes and cardiovascular events. Evidence-based nursing. eng.

Hornnes N, Larsen K, Boysen G. 2010. Little change of modifiable risk factors 1 year after stroke: a pilot study. International. Journal of Stroke. 5(3):157-62. 
Joanna Briggs Institute 2017, Checklist for Systematic Reviews and Research Syntheses, viewed $24^{\text {th }}$ August 2020, <https://joannabriggs.org/sites/default/files/2019-05/JBI Critical AppraisalChecklist for Systematic Reviews2017 0.pdf $>$

Kavanagh B. P. 2009. The GRADE system for rating clinical guidelines. PLoS medicine, 6(9), e1000094. https://doi.org/10.1371/journal.pmed.1000094

Kikuchi K, Kawahara KI, Miura N, Ito T, Morimoto Y, Tancharoen S, Takeshige N, Uchikado H, Sakamoto R, Miyagi N et al. 2012. Secondary prevention of stroke: Pleiotropic effects of optimal oral pharmacotherapy. Exp Ther Med. 4(1):3-7.

Mateen FO, J. Tergas, Al. Bhayani, NH. Kamdar, BB. 2013. Titles versus titles and abstracts for initial screening of articles for systematic reviews. Clinical epidemiology. 5:89-95. eng.

McAlister F, Grover S, Padwal J, Youngson E, Fradette M, Thompson A, et al. 2014. Case management reduces global vascular risk after stroke: secondary results from the preventing recurrent vascular events and neurological worsening through intensive organized casemanagement randomized controlled trial. American Heart Journal. 168(6):924-30.

Michael KM, Allen JK, Macko RF. 2005. Reduced ambulatory activity after stroke: the role of balance, gait, and cardiovascular fitness. Arch Phys Med Rehabil. 86(8):1552-1556.

Noblit GWH, R D. . 1988. Meta-Ethnography: Synthesizing Qualitative Studies. New York: SAGE Publications, Inc.

Norrving B, Kissela B. 2013. The global burden of stroke and need for a continuum of care. Neurology. 80(3 Suppl 2):S5-12.

O'Carroll R, Chambers J, Dennie M, Sudlow C, Johnston M. 2013. Improving adherence to medication in stroke survivors: a pilot randomised controlled trial. Annuals of Behavioural Medicine. 46(3):35868.

O'Donnell MJ, Xavier D, Liu L, Zhang H, Chin SL, Rao-Melacini P, Rangarajan S, Islam S, Pais P, McQueen MJ et al. 2010. Risk factors for ischaemic and intracerebral haemorrhagic stroke in 22 countries (the INTERSTROKE study): a case-control study. Lancet (London, England). 376(9735):112123.

Park JH, Ovbiagele B. 2015. Optimal combination treatment and vascular outcomes in recent ischemic stroke patients by premorbid risk level. J Neurol Sci. 355(1-2):90-93.

Peng B, Ni J, Anderson C, Zhu Y, Wang Y, Pu C, et al. (2014) Implementation of a structured guidelinebased program for the secondary prevention of ischemic stroke in China. Stroke. 45(2):515-9.

Rathbone J, Albarqouni L, Bakhit M, Beller E, Byambasuren O, Hoffmann T, Scott AM, Glasziou P. 2017. Expediting citation screening using PICo-based title-only screening for identifying studies in scoping searches and rapid reviews. Systematic Reviews. 6(1):233.

Schardt C, Adams MB, Owens T, Keitz S \& Fontelo P. (2007) Utilization of the PICO framework to improve searching PubMed for clinical questions. BMC Medical Informatics and Decision Making. 7 (16).

Toyoda K. 2009. Pharmacotherapy for the secondary prevention of stroke. Drugs. 69(6):633-647. 
Waffenschmidt S, Knelangen M, Sieben W, Bühn S, Pieper D. 2019. Single screening versus conventional double screening for study selection in systematic reviews: a methodological systematic review. BMC Medical Research Methodology. 19(1):132.

Walsh D, Downe S. 2006. Appraising the quality of qualitative research. Midwifer; 22:108-19.

Wan L, Zhang X, Mo M, Xiong X, Ou C, You L, et al. 2016 Effectiveness of goal-setting telephone follow-up on health behaviors of patients with ischemic stroke: a randomized controlled trial. Journal of Stroke and Cerebrovascular Diseases. 25(9):2259

Wells GS, B. O'Connell, D. Peterson, J. Welch, V. Losos, M. Tugwell, P. . 2019. The Newcastle- Ottawa Scale (NOS) for assessing the quality of nonrandomised studies in meta-analyses.

van Wijk I, Kappelle L, van Gijn J, Koudstaal PJ, Franke CL, Vermeulen M, Gorter JW, Algra A. 2005. Long-term survival and vascular event risk after transient ischaemic attack or minor ischaemic stroke: a cohort study. Lancet (London, England). 365(9477):2098-2104. eng.

World Health Organisation 2003, Adherence to long-term therapies evidence for action, viewed $24^{\text {th }}$ August 2020, <https://www.who.int/chp/knowledge/publications/adherence report/en/>

Zhang J, Gong Y, Zhao Y, Jiang N, Wang J, Yin X. 2019. Post-stroke medication adherence and persistence rates: a meta-analysis of observational studies. J Neurol. 